\section{JURNAL LAMPUHYANG \\ LEMBAGA PENJAMINAN MUTU \\ STKIP AGAMA HINDU AMLAPURA}

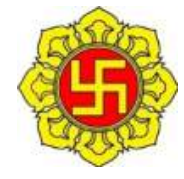

Volume 12 Nomor 2 Juli 2021

p-ISSN: 2087-0760; e-ISSN: 2745-5661

https://e-journal.stkip-amlapura.ac.id

\title{
Implementasi Pembelajaran Berbasis Blended Learning di STKIP Agama Hindu Amlapura pada Masa Pandemi
}

\author{
Nyoman Ayu Sri Desi Ariani \\ STKIP Agama Hindu Amlapura \\ ayudesi1886@gmail.com
}

Direvisi: 23 Juni 2021

Diterima: 28 Juni 2021

Diterbitkan: 1 Juli 2021

\begin{abstract}
Abstrak: Penelitian ini menggunakan metode penelitian deskriptif kualitatif yang bertujuan untuk mendeskripsikan model blended learning yang diimplementasikan di STKIP Agama Hindu Amlapura pada masa pandemi Covid-19 dan mendeskripsikan media yang digunakan dalam implementasi blended learning tersebut. Penelitian ini dilakukan pada semester ganjil tahun pelajaran 2020/2021 dengan subjek dosen dan mahasiswa STKIP Agama Hindu Amlapura. Data dikumpulkan dengan metode observasi, dokumentasi, dan wawancara, lalu dianalisis secara deskriptif kualitatif. Berdasarkan hasil analisis data ditemukan bahwa metode blended learning yang digunakan di STKIP Agama Hindu Amlapura pada masa pandemi adalah metode flex dan media yang digunakan adalah media google group, di antaranya google form, google meet, dan zoom.
\end{abstract}

Kata Kunci: Pembelajaran, Blended Learning, Pandemi

Abstrac: This study uses a qualitative descriptive research method that aims to describe the blended learning model implemented in the STKIP Agama Hindu Amlapura during the Covid-19 pandemic and describe the media used in the implementation of blended learning at the STKIP Agama Hindu Amlapura during the Covid-19 pandemic. This research was conducted in the odd semester of the 2020/2021 academic year with the subject of lecturers and students of the Hindu Religion STKIP Amlapura. Data were collected by means of observation, documentation and interviews and analyzed descriptively qualitatively. Based on the results of data analysis, it was found that the blended learning method used during the pandemic at STKIP Hinduism Amlapura was the flex method and the media used was the google group media, including google form, google meet, zoom.

Key words: Learning, Blended Learning, Pandemic 


\section{PENDAHULUAN}

\subsection{Latar Belakang Masalah}

Memasuki tahun 2020, dunia digemparkan oleh virus mematikan yang berasal mula dari Cina. Dan dalam waktu sekejam WHO sudah mengumumkan bahwa virus tersebut sudah menjadi pandemi. Tepat 16 Maret 2020, Indonesia memasang alarm terhadap penyebaran virus corona atau lebih dikenal Covid-19. Hal tersebut berdampak pada segala lini kehidupan, tidak terkecuali pendidikan.

Sekolah ditutup, kampus ditutup. Pembelajaran dilakukan di rumah. Guru/dosen mengajar dari rumah. Siswa/mahasiswa belajar di rumah. Semua hal dianjurkan dilakukan dari rumah. Pertanyaannya, bagaimana pembelajaran dilakukan dari rumah?

Hal tersebut terjawab oleh teknologi. Teknologi memungkinkan pembelajaran dilakukan dari rumah. Berbagai media/platform edukasi tersedia dan bisa diakses melalui leptop, computer ataupun smartphone.

Untuk menghadapi berbagai persoalan kegiatan pembelajaran pada masa pandemi berbagai alternatif model pembelajaran pun menjadi pilihan.
Model pembelajaran blended learning diterapkan di masa pandemi ini. Penelitian ini fokus kepada model pembelajaran dan platform blended learning yang digunakan oleh STKIP Agama Hindu Amlapura.

\subsection{Rumusan Masalah}

Berdasarkan latar belakang yang telah diuraikan di atas, maka permasalahan yang akan diteliti dalam penelitian ini sebagai berikut.

1. Apa saja model blended learning yang diimplementasikan di STKIP Agama Hindu Amlapura pada masa pandemi Covid-19?

2. Apa saja platform yang digunakan dalam implementasi blended learning di STKIP Agama Hindu Amlapura pada masa pandemi Covid-19?

\subsection{Tujuan Penelitian}

Tujuan penelitian ini adalah untuk:

1. mendeskripsikan model blended learning yang diimplementasikan di STKIP Agama Hindu Amlapura pada masa pandemi Covid-19. 
2. mendeskripsikan media yang digunakan dalam implementasi blended learning di STKIP Agama Hindu Amlapura pada masa pandemi Covid-19.

\subsection{Manfaat Penelitian}

1. Bagi mahasiswa, hasil penelitian ini dapat memberi motivasi dan semangat baru bagi mahasiswa dalam perkuliahan, membantu dalam pembelajaran mandiri dengan bertambahnya referensi untuk dijadikan panduan mengembangkan penelitian atau skripsi untuk tugas akhir.

2. Bagi dosen, hasil penelitian ini sebagai ajakan untuk terus mengembangkan penelitian yang berhubungan dengan blended learning.

3. Bagi institusi, hasil penelitian ini sebagai referensi untuk mengembangkan penelitianpenelitian terkait yang berhubungan dengan implementasi blended learning.

\section{TINJAUAN PUSTAKA \\ 2.1 Pembelajaran Berbasis Blended Learning}

Salah satu model pembelajaran yang dapat diterapkan melalui penggunan media berbasis teknologi adalah model blended learning. Secara ketatabahasaan istilah blended learning terdiri dari dua kata yaitu, blended dan learning. Blended atau berasal dari kata blend yang berarti "campuran, bersama untuk meningkatkan kualitas agar bertambah baik" (Collins Dictionary), atau formula suatu penyelarasan kombinasi atau perpaduan (Oxford English Dictionary), sedangkan learning berasal dari learn yang artinya "belajar". Oleh karena itu, secara sepintas istilah blended learning dapat diartikan sebagai campuran atau kombinasi dari pola pembelajaran satu dengan yang lainnya.

$\begin{array}{lrr}\text { Staker \& Horn } & \text { (2012) } \\ \text { mendefinisikan } & \text { blended } & \text { learning } \\ \text { sebagai pembelajaran } & \text { yang } \\ \text { mengkombinasikan } & \text { antara } \\ \text { pembelajaran } & \text { online } & \text { dengan } \\ \text { pembelajaran } & \text { konvensional } & \text { (tatap } \\ \text { muka). Pada pembelajaran model ini, } \\ \text { peserta didik difasilitasi untuk dapat }\end{array}$


belajar dan mengulang materi secara mandiri untuk satu bagian sesi menggunakan bahan dan sumber belajar online dan satu bagian sesi lainnya dilakukan secara tatap muka di dalam ruangan kelas.

Pembelajaran blended learning tidak hanya sekedar mengintegrasikan teknologi dalam pembelajaran di kelas. Namun dalam pembelajaran blended learning keberadaan teknologi lebih difokuskan untuk memfasilitasi peserta didik dalam mengeskplorasi materi bahan ajar dan mendapatkan pengalaman belajar secara mandiri. Dalam model pembelajaran ini, sesi online dan sesi tatap muka berjalan saling melengkapi dan berkesinambungan. Artinya, pada sesi pembelajaran online membahas materi dan kegiatan pembelajaran pada sesi tatap muka, begitu juga sebaliknya.

Ada banyak model yang dapat digunakan guru untuk mengaplikasikan aktifitas pembelajaran online dan tatap muka dalam pembelajaran blended learning. Clayton Christensen Institute telah mengindentifikasi beberapa model yang cukup sering digunakan dalam menyusun pembelajaran 'blended learning'.

1) Model Rotasi (Rotation Model)

Pada model kelas ini peserta didik akan diatur untuk bergantian menempati pos-pos kegiatan pembelajaran yang telah disediakan. Misalnya akan ada pos untuk kegiatan diskusi, mengerjakan proyek, tutorial secara individual, dan mengerjakan tugas atau latihan.

2) Model Kelas Flex

Pada model kelas flex, sebagian besar pembelajaran dilakukan secara online sehingga pembelajaran bersifat sangat fleksibel. Peserta didik dapat belajar sesuai dengan kemampuan, kebutuhan dan kecepatan belajar masing- masing. Pada model kelas ini, guru dapat berperan sebagai fasilitator melalui sesi diskusi, pengerjaan proyek dalam kelompok, maupun tutoring secara individu. Hal ini dimaksudkan untuk membantu peserta didik yang mengalami permasalahan dalam pembelajaran berdasarkan hasil pantauan aktifitas pembelajaran online yang telah dilaksanakan. Model kelas flex memerlukan perencanaan dan persiapan yang matang. Terdapat pula 
fasilitas bagi peserta didik untuk dapat berdiskusi langsung dengan guru secara online ketika menemui permasalahan dalam pembelajaran. Kunci dari model kelas flex adalah guru dapat memfasilitasi pembelajaran yang sangat fleksibel bagi peserta didik namun tetap ada interaksi yang bermakna antar peserta didik dan guru selama kegiatan pembelajaran.

\section{3) Model Self-Blend}

Pada model ini, peserta didik dapat mengambil satu atau lebih kegiatan pembelajaran online sebagai tambahan dari kegiatan pembelajaran tatap muka yang telah dilakukan. Contohnya adalah Sekolah Quakertown Community di Pennsylvania menawarkan pembelajaran online untuk peserta didik kelas 6-12. Pembelajaran online ini dirancang untuk dapat diakses baik di lingkungan sekolah (cyber lounge) maupun di tempat lainnya. Guru yang memfasilitasi pembelajaran online adalah guru yang juga mengajar pada sesi pembelajaran tatap muka.

4) Model Enriched-Virtual

Pada model kelas ini program pembelajaran dibagi menjadi dua sesi, yaitu pembelajaran tatap muka dan pembelajaran secara online. Pada awalnya model kelas enriched-virtual sepenuhnya adalah model kelas online. Namun pada perkembangannya ditambahkan model blended learning untuk memfasilitasi peserta didik melalui pembelajaran tatap muka. Model enriched-virtual berbeda dengan model flipped karena pembelajaran tatap muka dalam model enrichedvirtual tidak dilakukan setiap hari. Model kelas ini juga berbeda dengan model Self-Blend karena pembelajaran yang ditawarkan adalah kegiatan pembelajaran secara utuh, bukan berupa materi secara khusus.

\subsection{Program Aplikasi atau Platform untuk Pembelajaran Model Blended}

Berikut beberapa aplikasi yang dapat digunakan untuk pembelajaran yang menggunakan model blended learning:

(a) Web 2.0

Salah satu jenis web 2.0 yang digunakan untuk model blended learning adalah aplikasi software sistem manajemen pembelajaran (Learning management System - 
LMS) yaitu Moodle. Melalui platform ini, guru dapat mengunggah konten dan materi belajar, mengunggah media pembelajaran (power point atau flash), kegiatan diskusi online, kuis, dll. Berikut merupakan contoh platform yang dapat digunakan untuk membuat Moodle, yaitu Keytoschool.

(b) Edmodo

Edmodo pertama kali dikembangkan pada akhir tahun 2008 oleh Nic Borg dan Jeff O’Hara. Guru dapat memanfaatkan Edmodo untuk beberapa hal seperti:

Berkomunikasi dengan siswa dan orangtua siswa

$$
\begin{aligned}
& \text { Memonitor aktifitas } \\
& \text { pembelajaran online } \\
& \text { ujian } \\
& \text { Membuat kuis, latihan, atau } \\
& \text { Mengunggah materi belajar }
\end{aligned}
$$

Edmodo ini dapat diakses dimana saja dan kapan saja. Platform ini juga memiliki fitur berupa lencana atau badge sebagai penghargaan yang dapat diberikan kepada siswa atas progress belajarnya.

(c) Google Group
Selain sebagai mesin
pencarian informasi (search
engine), dalam perkembangannya Google juga menyediakan beberapa fitur yang memfasilitasi pengguna untuk berkomunikasi dan berkolaborasi secara online yang dapat digunakan untuk pembelajaran dimana saja, kapan saja, dan diperangkat apa saja melalui $G$ Suite for Education. Berikut merupakan fitur yang disediakan:

Gmail. Berupa sistem yang dapat digunakan untuk untuk saling berkirim email secara aman dengan kelas atau sekolah.

Drive. Berupa sistem yang dapat digunakan untuk menyimpan dan mengorganisir tugas, dokumen, atau kurikulum kelas.

Kalender. Dapat digunakan untuk membagikan atau membuat jadwal suatu kegiatan bersama dengan siswa. Melalui aplikasi ini, guru dan siswa akan mendapatkan pengingat akan jadwal suatu kegiatan yang dapat diatur beberapa hari sebelumnya. 
Dokumen, Spreadsheet, dan

Slide. Fitur ini dapat digunakan untuk

berkolaborasi, berbagi

masukan, dan bekerja sama

dengan siswa secara real

time di dokumen,

spreadsheet, dan

presentasi.

Formulir. Fitur ini dapat

digunakan untuk membuat

formulir, kuis, dan survei

untuk mengumpulkan dan

menganalisis jawaban.

Jamboard. Jamboard

merupakan sebuah

smartboard berbasis cloud

dari Google, di komputer,

ponsel, atau tablet yang

dapat digunakan untuk

membuat sketsa dan

berkolaborasi dengan

siswa menggunakan

kanvas interaktif.

Sites. Web builder yang dapat

digunakan untuk membuat situs,

menjadi host kurikulum

pelajaran, membangun

keterampilan pengembangan, dan memfasilitasi kreativitas siswa.

Hangouts Meet. Fitur ini memungkinkan guru untuk terhubung dengan siswa secara virtual melalui video call dan pengiriman pesan yang aman agar pembelajaran tetap berlangsung meskipun di luar sekolah.

Grup. Fitur ini dapat digunakan untuk membuat forum diskusi secara online guna meningkatkan kemampuan komunikasi dan keterlibatan siswa dalam suatu topik diskusi. Vault. Dapat digunakan untuk mengelola perangkat yang terhubung dalam kelas online, mengkonfigurasikan keamanan dan setelan agar data tetap aman.

\subsection{Pandemi Covid-19}

Pandemi COVID-19 adalah peristiwa menyebarnya Penyakit koronavirus 2019 (Bahasa Inggris: Coronavirus disease 2019, disingkat COVID-19) di seluruh dunia untuk semua Negara. Penyakit ini disebabkan oleh koronavirus jenis baru 
yang diberi nama SARS-CoV-2. Wabah COVID-19 pertama kali dideteksi di Kota Wuhan, Provinsi Hubei, Tiongkok pada tanggal 1 Desember 2019, dan ditetapkan sebagai pandemi oleh Organisasi

Kesehatan Dunia (WHO) pada tanggal 11 Maret 2020. Hingga 14 November 2020, lebih dari 53.281 .350 orang kasus telah dilaporkan lebih dari 219 negara dan wilayah seluruh dunia, mengakibatkan lebih dari 1.301.021 orang meninggal dunia dan lebih dari 34.394.214 orang sembuh.

Upaya untuk mencegah penyebaran virus corona termasuk pembatasan perjalanan, karantina, pemberlakuan jam malam, penundaan dan pembatalan acara, serta penutupan fasilitas. Upaya ini termasuk karantina Hubei, karantina nasional di Italia dan di tempat lain di Eropa, serta pemberlakuan jam malam di Tiongkok dan Korea Selatan, berbagai penutupan perbatasan negara atau pembatasan penumpang yang masuk, penapisan di bandara dan stasiun kereta, serta informasi perjalanan mengenai daerah dengan transmisi lokal. Sekolah dan universitas telah ditutup baik secara nasional atau lokal di lebih dari 124 negara dan memengaruhi lebih dari 1,2 miliar siswa.

Pandemi ini telah menyebabkan gangguan sosioekonomi global, penundaan atau pembatalan acara olahraga dan budaya, dan kekhawatiran luas tentang kekurangan persediaan barang yang mendorong pembelian panik. Misinformasi dan teori konspirasi tentang virus telah menyebar secara daring, dan telah terjadi insiden xenophobia dan rasisme terhadap orang Tiongkok dan orang-orang Asia Timur atau Asia Tenggara lainnya.

\subsection{Pembelajaran Selama Pandemi Covid-19}

Pandemi Covid-19 yang
mewabah di berbagai penjuru dunia
berimbas pada berbagai sektor
kehidupan masyarakat. Bukan hanya
kesehatan dan ekonomi, dunia
pendidikan pun sangat terpengaruh
dengan pandemi yang pertama kali
diumumkan masuk Indonesia pada 2
Maret 2020. Kebijakan jaga jarak dan
tidak berkerumun mengakibatkan
pemerintah menerbitkan kebijakan


khusus pembelajaran di lembaga pendidikan.

Kebijakan pertama dilakukan melalui Surat Edaran Nomor 4 Tahun 2020 tentang Pelaksanaan Kebijakan Pendidikan Dalam Masa Darurat Penyebaran Corona Virus Desease (Covid-19). Pada kebijakan ini, diputuskan larangan pelaksanaan pembelajaran tatap muka di sekolah yang berlaku hingga akhir tahun pelajaran 2019/2020.

Saat memasuki tahun pelajaran 2020/ 2021, pemerintah kembali mengeluarkan aturan baru tentang pelaksanaan pendidikan melalui SKB 4 Menteri, yaitu Menteri Pendidikan dan Kebudayaan, Menteri Agama, Menteri Kesehatan, dan Menteri dalam Negeri masing-masing No. 01/KB/2020, No. 516 Tahun 2020, No. Hk.03.01/Menkes/363/2020, dan No. 440-882 Tahun 2020.

Kebijakan ini mengatur penyelenggaraan pembelajaran tetap berjalan dalam masa pandemi dengan mempertimbangkan pembagian zona wilayah yang dikeluarkan oleh Gugus Tugas Percepatan Penanganan Covid19. Namun melalui kebijakan ini,
Pemerintah berprinsip tetap fokus mengedepankan dan mengutamakan kesehatan dan keselamatan seluruh elemen lembaga pendidikan.

Disebutkan dalam SKB ini bahwa untuk daerah yang berada di zona oranye dan merah, tetap dilarang melakukan pembelajaran tatap muka di satuan pendidikan. Sekolah pada zonazona tersebut tetap melanjutkan Belajar dari Rumah (BDR).

Sementara zona hijau dan kuning dapat diperbolehkan untuk melakukan pembelajaran tatap muka dengan pertimbangan risiko kesehatan yang tidak berbeda jauh dengan zona hijau. Pembelajaran tatap muka di zona hijau atau kuning juga bisa dilaksanakan jika pemerintah daerah dan orang tua atau wali mengizinkan untuk tatap muka.

Tahapan pembelajaran tatap muka satuan pendidikan di zona hijau dan zona kuning dilakukan secara bersamaan pada jenjang pendidikan dasar dan menengah dengan pertimbangan risiko kesehatan yang tidak berbeda untuk kelompok umur pada dua jenjang tersebut. Sementara itu untuk PAUD dapat memulai 
pembelajaran tatap muka paling cepat dua bulan setelah jenjang pendidikan dasar dan menengah.

Sementara untuk pembelajaran praktik yang merupakan keahlian inti SMK, diperbolehkan di semua zona dengan wajib menerapkan protokol kesehatan yang ketat. Madrasah dan sekolah berasrama di zona hijau dan zona kuning juga dapat membuka asrama dan melakukan pembelajaran tatap muka secara bertahap sejak masa transisi.

Kapasitas asrama dengan jumlah peserta didik kurang dari atau sama dengan 100 orang pada masa transisi bulan pertama adalah 50 persen, bulan kedua 100 persen, kemudian terus dilanjutkan 100 persen pada masa kebiasaan baru. Untuk kapasitas asrama dengan jumlah peserta didik lebih dari 100 orang, pada masa transisi bulan pertama 25 persen, dan bulan kedua 50 persen, kemudian memasuki masa kebiasaan baru pada bulan ketiga 75 persen, dan bulan keempat 100 persen.

$$
\text { Seiring diterapkannya }
$$

kebijakan pembelajaran di semester pertama (ganjil) tahun pelajaran 2019/2020 ini, berbagai kendala dihadapi. Banyak pihak menilai pembelajaran daring atau pembelajaran jarak jauh (PJJ) berjalan tidak efektif. Banyak pihak menilai jika kebijakan ini diteruskan maka akan berimbas pada siswa, dalam bentuk penurunan kemampuan belajar (learning loss).

$$
\text { Di antara kendala yang }
$$
dihadapi adalah kurangnya persiapan segenap insan pendidikan terhadap datangnya wabah Covid-19 yang datang tiba-tiba. Di tambah lagi sarana dan prasarana yang mendukung pembelajaran daring tidak tersedia secara merata di berbagai daerah di Indonesia. Termasuk juga tingkat kemampuan ekonomi dan kesempatan orang tua siswa juga ikut mempengaruhi tidak maksimalnya pembelajaran di masa pandemi.

Dari sisi siswa, pembelajaran daring juga sangat melelahkan melebihi pembelajaran tatap muka. Pasalnya pembelajaran daring lebih banyak memberikan tugas yang membebani fisik dan metal mereka. Jika hal ini terjadi secara terus-menerus, maka efek lain bisa saja muncul seperti stres, jenuh, dan pada akhirnya pelajar akan 
depresi dan tak peduli terhadap tugas yang diberikan.

Pada sistem pembelajaran daring, para pendidik juga banyak mengeluh tidak maksimalnya pendidikan dari sisi afektif. Karakter, kedisiplinan, etika, dan hal-hal menyangkut psikologi anak didik tidak terajarkan dengan baik.

Menteri Pendidikan Nadiem Makarim sendiri mengakui bahwa pembelajaran daring memiliki sedikitnya tiga dampak negatif yakni ancaman putus sekolah karena pelajar terus berada di rumah, penurunan capaian belajar, dan kekerasan pada anak.

Setelah melakukan evaluasi dan menerima berbagai masukan dari berbagai pihak, akhirnya pemerintah memperbolehkan kegiatan pembelajaran tatap muka oleh satuan pendidikan untuk semester genap tahun 2020/2021.

Kebijakan yang akan dimulai pada Januari 2021 ini tertuang dalam Keputusan Bersama Menteri Pendidikan dan Kebudayaan, Menteri Agama, Menteri Kesehatan, dan Menteri Dalam Negeri Republik
Indonesia tentang Panduan Penyelenggaraan Pembelajaran pada Tahun Ajaran 2020/2021 dan Tahun Akademik 2020/2021 di Masa Pandemi Coronavirus Disease 2019 (Covid-19). Dalam kebijakan baru ini, pemerintah daerah adalah pihak yang paling dapat menentukan apakah daerahnya bisa segera melakukan pembelajaran tatap muka atau belum. Hal ini karena Pemda lebih mengetahui kondisi, kebutuhan dan kapasitas serta keamanan situasi Covid-19 di wilayahnya.

Namun Pengurus Pusat Persatuan Guru Nahdlatul Ulama (Pergunu) menilai Surat Keputusan Bersama (SKB) pemerintah terkait kegiatan pembelajaran tatap muka tidak tegas dan menyulitkan. Melalui Ketua Pengurus Pusat Pergunu, Aris Adi Leksono, Pergunu meminta kesiapan pemerintah menanggung sarana pra sarana protokol kesehatan (prokes).

$$
\text { Pergunu menilai prosedural }
$$
yang telah ditetapkan pemerintah tidak semudah yang dibayangkan, sebab perlu koordinasi yang intens bahkan rekomendasi dari Pemerintah Daerah (Pemda). 
Hal-hal ini tentu akan memperlambat implementasi kebijakan oleh pihak sekolah untuk dapat dilaksanakan. Pemerintah pusat dalam hal ini seolah-olah lepas tangan dan melempar tanggung jawab kepada sekolah secara sepihak. Jika terjadi sesuatu hal, otomatis sekolah yang akan disalahkan.

\section{METODE PENELITIAN}

Penelitian ini merupakan penelitian deskriptif kualitatif yang dilaksanakan di STKIP Agama Hindu pada semester ganjil tahun pelajaran 2020/2021. Penelitian deskriptif kualitatif adalah rangkaian kegiatan untuk memperoleh data yang bersifat apa adanya tanpa ada dalam kondisi tertentu yang hasilnya lebih menekankan makna. Di sini, peneliti menggunakan metode penelitian deskriptif kualitatif karena penelitian ini akan mengobservasi dan menyajikan data yang didapat secara deskriptif dari hasil observasi dan wawancara dosen dan mahasiswa STKIP Agama Hindu Amlapura. Data dikumpulkan dengan metode observasi, dokumentasid an wawancara. Sedangkan data dianalisis dengan model interaktif dengan langkah-langkah mengobservasi perilaku siswa pada saat proses pembelajaran di STKIP Agama Hindu Amlapura, melakukan wawancara dengan dosen dan mahasiswa, membaca dan menjabarkan pernyataan dari guru dan siswa, mencaridefinisi dan mencatat hal-hal pentingyang berkaitan dengan konsep-konsep kunci yang telah ditetapkanbaik berupa pernyataan, definisi, unsur-unsur dan sebagainya, mengkategorikan catatancatatan yang diambil dari sumber data lalu mengklasifikasikannya ke dalam kategori yang sama, mengkategorikan kategori yang telah disusun dan dihubungkan dengan kategori lainnya sehingga hasilnya akan diperoleh susunanyang sistematis dan berhubungan satu sama lain, menelaah relevansi data dengan cara mengkaji susunan pembicaraan yang sitematik dan relevansinya serta tujuan penelitian, melengkapi data dengan cara mengkaji isi data baik berupa hasil observasi dan hasil wawancara serta hasil dokumentasi dilapangan, menjadikan jawaban, dan menyusun 
laporan, setelah menjabarkan jawaban secara terperinci, kemudian menyusunnya dalam bentuk laporan.

\section{HASIL DAN PEMBAHASAN}

\subsection{Hasil Penelitian}

Di awal-awal WFH dan BDR, seperti terjadi mati suri. Mahasiswa dan dosen yang gaptek tidak tau harus memulai dari mana. Semua kebingungan bagaimana cara berinteraksi melakukan proses belajar dan mengajar.

Namun seiring berjalannya waktu, sepertinya semua sudah terbiasa menggunakan teknologi untuk pembelajaran. Mahasiswa dan dosen yang dulunya gaptek kini sudah melek. Untuk itulah, penelitian ini bertujuan untuk mendokumentasikan model pembelajaran blended learning dan media pembelajaran blended leaning yang digunakan oleh dosen dan mahasiswa di lingkungan STKIP Agama Hindu Amlapura di masa pandemic covid-19.

Observasi dan wawancara dilakukan kepada 4 orang dosen yang merupakan Kaprodi di masing-masing program studi di STKIP Agama Hindu Amlapura dan 12 mahasiswa yang merupakan perwakilan masing-masing kelas di setiap prodi. Berdasarkan observasi dan wawancara yang dilakukan kepada dosen dan mahasiswa, ditemukan bahwa $100 \%$ dosen menggunakan model blended learning Flex.

Pada model kelas flex, sebagian besar pembelajaran dilakukan secara online sehingga pembelajaran bersifat sangat fleksibel. Mahasiswa belajar sesuai dengan kemampuan, kebutuhan dan kecepatan belajar masing- masing. Pada model kelas ini, dosen berperan sebagai fasilitator melalui sesi diskusi, pengerjaan proyek dalam kelompok, maupun tutoring secara individu. Hal ini dimaksudkan untuk membantu mahasiswa yang mengalami permasalahan dalam pembelajaran berdasarkan hasil pantauan aktifitas pembelajaran online yang telah dilaksanakan.

Berdasarkan hasil wawancara, model pembelajaran flex digunakan sesuai dengan surat edaran dari pemerintah yang belum mengijinkan perkuliahan tatap muka, demi keselamatan dan memutus rantai penyebaran covid-19. Sehingga, mau 
tidak mau, semua dosen dan mahasiswa harus melakukan pembelajaran online secara penuh.

Berdasarkan hasil observasi dan wawancara, media yang digunakan dalam implementasi blended learning di
STKIP Agama Hindu Amlapura adalah media google group, diantaranya google form, google meet, zoom. Media yang digunakan oleh dosen di masing-masing prodi dapat dilihat sebagai berikut.

Tabel 01 Pemanfaatan Media dalam Blended Learning

\begin{tabular}{|l|l|l|}
\hline No & Prodi & Media \\
\hline 1 & $\begin{array}{l}\text { Pendidikan } \\
\text { Bahasa Inggris }\end{array}$ & $\begin{array}{l}\text { Wa group, Google Meet, Zoom meeting, Google Classroom } \\
\text { Google Form, Gmail, Youtube }\end{array}$ \\
\hline 2 & $\begin{array}{l}\text { Pendidikan } \\
\text { Agama Hindu }\end{array}$ & $\begin{array}{l}\text { Wa group, Google Meet, Zoom meeting, Google Classroom } \\
\text { Google Form, Youtube }\end{array}$ \\
\hline 3 & $\begin{array}{l}\text { Pendidikan } \\
\text { Bahasa Bali }\end{array}$ & Wa group, Zoom meeting, Google Classroom, Youtube \\
\hline 4 & $\begin{array}{l}\text { Pendidikan Guru } \\
\text { Sekolah dasar }\end{array}$ & $\begin{array}{l}\text { Wa group, Google Meet, Zoom meeting, Google Classroom } \\
\text { Google Form, Gmail, Youtube }\end{array}$ \\
\hline
\end{tabular}

Berdasarkan tabel di atas dapat dilihat bahwa media yang digunakan oleh dosen dalam proses pembelajaran sangat variatif dan sesuai dengan pembelajaran abad-21 serta memenuhi anjuran pemerintah untuk tidak tatap muka.

\subsection{Pembahasan}

Pembelajaran blended learning adalah jawaban dari masalah yang dialami semua insan di dunia pendidikan setelah dilanda pandemic Covid-19. Pembelajaran harus dari rumah dan tidak boleh bertatap muka. Pembelajaran blended learning merupakan solusi yang diterapkan untuk pembelajaran jarak jauh.

Berdasarkan hasil temuan dalam penelitian ini, diketahui bahwa model blended learning yang digunakan oleh dosen di setiap prodi yaitu flex. Model Flex ini adalah salah satu model dari 3 model pembelajaran blended learning. Model ini digunakan dengan pertimbangan surat edaran pemerintah yang melarang pembelajaran tatap muka. Sementara itu, media yang digunakan bervariasi, seperti Wa group, Google Meet, Zoom meeting, Google Classroom, Google Form, Gmail, Youtube. Berdasarkan teori dalam Bab II, media 
dalam blended learning ada 3, yaitu web 2.0, Edmodo, google group. Namun, media yang digunakan di STKIP Agama Hindu Amlapura yaitu google group.

\section{PENUTUP}

\subsection{Simpulan}

Berdasarkan hasil analisis data dan pembahsan hasil penelitian yang telah diuraikan pada bab sebelumnya, maka dapat disimpulkan bahwa model blended learning yang diimplementasikan di STKIP Agama Hindu Amlapura di masa pandemicCovid-19 adalah model Flex. media yang digunakan dalam implementasi blended learning di STKIP Agama Hindu Amlapura di masa pandemic Covid-19 yaitu google group.

\subsection{Saran}

Berdasarkan simpulan di atas, dapat dikemukakan saran-saran sebagai berikut. Mahasiswa diharapkan dapat motivasi dan semangat baru dalam perkuliahan, membantu dalam pembelajaran mandiri dengan bertambahnya referensi untuk dijadikan panduan mengembangkan penelitian atau skripsi untuk tugas akhir. Dosen diharapkan untuk terus mengembangkan penelitian yang berhubungan dengan blended learning. Institusi diharapkan agar mendukung pembelajaran blended learning yang dilakukan dosen dan mahasiswa.

\section{DAFTAR RUJUKAN}

Brumfit, H.D. 1982. The Power of Student's Involvement: Using Posters as Teaching Tools in Managing Large Classes. Journal of English for Specific Purposes World, Vol.14, No. 40, ISSN 1682-3257.

Dichev et al., C. (2013). Current Practices, Trends and Challenges in K-12 Online Learning. Cybernetics and Information Technologies.Volume 13, Issue 3, Pages 91-110

Graham, C. R., Borup, J., Short, C. R., \& Archambault, L. (2019). K-12 Blended Teaching: A Guide to Personalized Learning and Online Integration By Freely accessible online at: Independently published.

He, N. Z. (2000). An investigation into English mixingin Chinese Internet language. World Journal of English Language, 1(2).

Prayitno, W. (2015). Implementasi blended learning dalam pembelajaran pada pendidikan dasar dan menengah. Yogyakarta, Indonesia. 
Staker, B. H., \& Horn, M. B. (2012). Classifying $\mathrm{K}-12$ Blended Learning.

California, USA: Innosight Institute, Inc.

Surjono, H. D. (2009). Membangun ELearning dengan Moodle. Retrieved from http://blog.uny.ac.id/hermansurj ono
Youssef, Y. (2015). Exploring $K$ 12 Blended Learning Models to Assist the Reform of Education in Egypt. (PH Ludwigsburg University of Education German and Helwan University Cairo). https://doi.org/10.13140/R G.2.1.3880.2321 